DOI https://doi.org/10.30525/978-9934-26-075-9-46

\title{
АКТУАЛЬНІСТЬ ФІЗИЧНОЇ ТЕРАПІЇ У РАЗІ МЕДІАЛЬНОГО ВЕЛИКОГОМІЛКОВОГО СТРЕС-СИНДРОМУ У КУРСАНТІВ ВИЩИХ ВІЙСЬКОВИХ НАВЧАЛЬНИХ ЗАКЛАДІВ
}

\author{
Купріненко О. В. \\ старший викладач кафедри фізичної терапії та ерготерапії \\ Львівський держсавний університет фізичної культури \\ імені Івана Боберського \\ Тимрук-Скоропад К. А. \\ доктор наук з фізичного виховання та спорту, доцент, \\ професор кафедри фізичної терапї та ерготерапії \\ Львівський держсавний університет фізичної культури \\ імені Івана Боберського \\ Ціж Л. М. \\ кандидат наук з фізичного виховання та спорту, доцент, \\ завідувач кафедри фізичної терапії та ерготерапії \\ Львівський державний університет фізичної культури \\ імені Івана Боберського \\ м. Львів, Украӥна
}

Медіальний великогомілковий стрес-синдром (medial tibial stress syndrome (MTSS), M76.80 за MКX) - це травма внаслідок надмірного використання або повторювальна травма ділянки гомілки [1, с. 127].

Проявляється болем задньомедіальної частини великогомілкової кістки, причиною якого $є$ значне фізичне навантаження, що призводить до мікротравм м'язів гомілки та перенапруження місць їх кріплення, періоститу великогомілкової кістки внаслідок іiї незначного згинання під дією навантаження [2].

Медіальний великогомілковий стрес-синдром (МВСС) найчастіше зустрічається серед спортсменів, зокрема, легкоатлетів та військовослужбовців й може значно обмежувати їх можливості виконувати професійні фізичні навантаження [3, с. 54].

Виникнення МВСС у спортсменів та військовослужбовців становить від 7,2\% до $35 \%$ [4, с. 362]. Особливо високий ризик отримати цю травму $\epsilon$ у військовослужбовців першого року служби до яких належать i курсанти вищих військових навчальних закладів (ВВН3) [5, с. 587]. 180 
Встановлено, що проходження первинної військово-професійної підготовки у курсантів може призводити до періоститу великогомілкової кістки у 10\% курсантів і 60-80\% усіх випадків пов'язані з кістковом'язовими перевантаженнями [6, с. 103].

Доведено, що МВСС можна попередити, використовуючи відповідні заходи фізичної терапії [7, с. 1319]. Особи, у яких виник цей синдром схильні до рецидивів захворювання і без надання належного лікування i реабілітації може розвинутись його хронічна форма, що призводить до обмеження функціонування. Окрім того, синдром вважається передумовою стресового перелому великогомілкової кістки, що потребує більш тривалого лікування та відновлення.

За результатами проведеного аналізу існуючих методичних підходів до фізичної терапії осіб з синдромом МВСС в Україні виявлено малу кількість публікацій, в яких розглядається ця проблема. Питання профілактики МВСС та реабілітації засобами фізичної терапії курсантів ВВН3 не досліджені українськими науковцями. Не виявлено розроблених та впроваджених комплексних програм профілактики МВСС та фізичної терапії курсантів у разі травми.

Недостатня кількість досліджень, відсутність програм фізичної терапії, які б сприяли швидкому відновленню і профілактиці медіального великогомілкового стрес-синдрому актуалізують дослідження у даному напрямку.

Зазначені обставини та важливість належної підготовки військових фахівців й підтримки їх фізичної працездатності i функціонування в умовах восьмого року війни на Сході України обумовлюють актуальність проведення відповідних досліджень.

\section{Література:}

1. Galbraith R.M., Lavallee M.E. Medial tibial stress syndrome: Conservative treatment options. Current Reviews in Musculoskeletal Medicine. 2009. 2. P. 127-133. DOI: 10.1007/s12178-009-9055-6.

2. Brown A.A. Medial tibial stress syndrome: muscles located at the site of pain. Scientifica (Cairo). 2016. 4 p. PMID: 27066291. PMCID: PMC4811262. DOI: $10.1155 / 2016 / 7097489$.

3. Sharma J., Heagerty R., Dalal S., Banerjee B., Booker T. Risk Factors Associated With Musculoskeletal Injury: A Prospective Study of British Infantry Recruits. Current Rheumatology Reviews. 2019. Vol. 15, № 1. P. 50-58. PMID: 29708075. DOI: 10.2174/ 1573397114666180430103855.

4. Hamstra-Wright K.L., Huxel Bliven K.C., Bay C. Risk factors for medial tibial stress syndrome in physically active individuals such as runners 
and military personnel: a systematic review and meta-analysis. British Journal of Sports Medicine. 2015. № 49. P. 362-369. PMID: 25185588. DOI: 10.1136/bjsports-2014-093462.

5. Garnock C., Witchalls J., Newman P.J. Predicting individual risk for medial tibial stress syndrome in navy recruits. Journal of Science and Medicine in Sport. 2018. Vol. 21. № 6. P. 586-590. PMID: 29122474. DOI: 10.1016/j.jsams. 2017.10.020.

6. Garcia S.G., Rona R.S., Gomez Tinoco M.C., Rodriguez M.B., Chaustre Ruiz D.M., Cardenas Letrado F.P., Lopez-Illescas Ruiz Á., Alarcon Garcia J.M. Shockwave treatment for medial tibial stress syndrome in military cadets: A single-blind randomized controlled trial. International Journal of Surgery. 2017. Vol. 46. P. 102-109. PMID: 28882773. DOI: $10.1016 /$ j.ijsu.2017.08.584.

7. Winters M., Eskes M., Weir A., Moen M.H., Backx J G.F., Bakker W P.E. Treatment of medial tibial stress syndrome: a systematic review. British Journal of Sports Medicine. 2013. Vol. 43. № 12. P. 1315-1333. PMID: 23979968 DOI: 10.1007/s40279-013-0087-0. 